\title{
Association of TNF- $\alpha$ Gene Variants With Clinical Manifestation of Cystic Fibrosis Patients of Iranian Azeri Turkish Ethnicity
}

\author{
Aziz Khorrami ${ }^{1, *}$; Mortaza Bonyadi ${ }^{1}$; Mandana Rafeey ${ }^{2}$; Omid Omrani ${ }^{1}$ \\ ${ }^{1}$ Faculty of Natural Science, University of Tabriz, Tabriz, IR Iran \\ ${ }^{2}$ Department of Pediatrics, Tabriz University of Medical Sciences, Tabriz, IR Iran \\ *Corresponding author: Aziz Khorrami, Faculty of Natural Science, University of Tabriz, Tabriz, IR Iran. Tel:+98-4133374322, Fax: +98-4133374323, E-mail: khorrami.a2013@yahoo.com
}

Received: December 12, 2014; Accepted: December 29, 2014

\begin{abstract}
Background: Cystic fibrosis (CF), a life-limiting autosomal recessive disorder, is considered a monogenic disease that is caused by mutations in the cystic fibrosis transmembrane conductance regulator (CFIR) gene. According to several studies, mutation analysis of the cystic fibrosis transmembrane conductance regulator (CFTR) gene alone is insufficient to predict the phenotypic manifestations observed in cystic fibrosis (CF) patients. In addition, some patients with a milder CF phenotype do not carry any pathogenic mutation. Tumor Necrosis Factor-alpha (TNF- $\alpha$ ) contributes to the pathophysiology of CF by causing cachexia. There is a reverse association between TNF- $\alpha$ concentration in patient's sputum and their pulmonary function.

Objectives: To assess the effect of non-CFTR genes on the clinical phenotype of CF, two polymorphic sites (-1031T/C and -308G/A) of the TNF- $\alpha$ gene, as a modifier, were studied.

Patients and Methods: Focusing on the lung and gastrointestinal involvement as well as the poor growth, we first investigated the role of TNF- $\alpha$ gene in the clinical manifestation of CF. Furthermore, based on the hypothesis that the cumulative effect of specific alleles of multiple CF modifier genes, such as TNF- $\alpha$, may create the final phenotype, we also investigated the potential role of TNF- $\alpha$ in non-classic CF patients without a known pathogenic mutation. In all, 80 CF patients and 157 healthy control subjects of Azeri Turkish ethnicity were studied by the PCR-RFLP method. The chi-square test with Yates' correction and Fisher's exact test were used for statistical analysis.

Results: The allele and genotype distribution of the investigated polymorphisms, and their associated haplotypes were similar in all groups.

Conclusions: There was no evidence that supported the association of TNF- $\alpha$ gene polymorphisms with non-classic CF disease or the clinical presentation of classic $\mathrm{CF}$.
\end{abstract}

Keywords: Cystic Fibrosis; Gene; Tumor Necrosis Factor-alpha

\section{Background}

Cystic fibrosis (CF), a life-limiting autosomal recessive disorder, is considered a monogenic disease that is caused by mutations in the cystic fibrosis transmembrane conductance regulator (CFTR) gene $(1,2)$. However, recent studies have revealed that some patients with a milder CF phenotype do not carry any CFTR gene mutation (3). Located on chromosome 7q31.2, the CFTR gene contains 27 exons and encodes a 1480-aminoacid protein that acts as a cyclic adenosine monophosphate (cAMP)-regulated chloride channel in the apical membrane of epithelial cells (4). Following the identification of the CFTR gene in 1989 , it has been found that the $\Delta \mathrm{F} 508$ mutation is responsible for approximately $70 \%$ of the CF cases worldwide (5). To date, more than 1932 mutations have been identified (6). The clinical course of CF includes chronic airway inflammation and recurrent infections that result in progressively deteriorating lung function. The manifestation of CF also includes gastrointestinal problems, growth failure, and male infertility (7). The widely varying phenotypic expression of CF is likely caused by the
CFTR allelic heterogeneity and environmental factors (8). The disease variability among patients who share a particular CFTR genotype and similar environment maybe because of additional genetic variations contribute to such variability in the phenotypic expression of $\operatorname{CF}(9,10)$. Genes that interact with the disease-causing mutation are responsible for specific phenotypic alterations and are known as genetic modifiers. Genetic modifiers alter the penetrance, expressivity, pleiotropy, and severity of a phenotype and may play protective roles or increase the susceptibility to disease (11). The gene encoding tumor necrosis factor- $\alpha$ (TNF- $\alpha$ ), an endogenous pro-inflammatory cytokine, acts as a modifier gene $(8,9)$. This gene is located on chromosome $6 \mathrm{p} 21.3$, in the class III region of the HLA (12). It has been reported that single nucleotide polymorphisms (SNPs) in the TNF- $\alpha$ promoter region can lead to increased TNF- $\alpha$ production $(13,14)$. How these polymorphisms alter the susceptibility to systemic lupus erythematosus, insulin-dependent diabetes, and inflammatory bowel disease has been examined $(15,16)$. Previous stud-

Copyright (C) 2015, Growth \& Development Research Center. This is an open-access article distributed under the terms of the Creative Commons Attribution-NonCommercial 4.0 International License (http://creativecommons.org/licenses/by-nc/4.0/) which permits copy and redistribute the material just in noncommercial usages, provided the original work is properly cited. 
Khorrami A et al.

ies revealed an association between the number of polymorphic sites of this gene and severe CF phenotype. TNF- $\alpha$ up regulates the activity of other pro-inflammatory cytokines, reduces the concentrations of Growth Hormone $(\mathrm{GH})$, and inhibits the production of insulin-like growth factor 1 (IGF-1) in the skeletal muscle $(17,18)$. High levels of TNF- $\alpha$ is associated with increased protein catabolism, muscle wasting, and decreased growth and regeneration of skeletal muscle (19). Additionally, TNF- $\alpha$ promotes the neutrophil-dominated inflammatory response, and is inversely correlated with lung function in CF patients (8, 9). The pulmonary phenotype in CF patients is variable including in those who share the same CFTR genotype, and are influenced by secondary genetic factors such as TNF- $\alpha$ gene (20). Regarding the single nucleotide polymorphisms (SNPs) in the promoter region of the TNF- $\alpha$ gene, it has been shown that the $-1031 \mathrm{C}$ and $-308 \mathrm{~A}$ alleles contribute to increased TNF- $\alpha$ production $(13,14)$.

\section{Objectives}

Therefore, the objective of the current study was to investigate the possible relationship between the TNF- $\alpha$ gene 1031T/C and TNF- $\alpha$ 308G/A polymorphisms and the susceptibility to CF disease in patients with no CFTR mutation, and with clinical manifestations in CF patients with homozygous $\Delta$ F508 mutation.

\section{Materials and Methods}

\subsection{Subjects}

Eighty unrelated Azeri Turkish CF patients were enrolled in this study. Of these patients, 30 were homozygous for $\Delta$ F508 and 50 carried no known mutation, but presented the symptoms of $\mathrm{CF}$ (samples had been screened for $>90 \%$ of all familiar mutations). The diagnostic criteria included positive sweat tests and typical clinical findings of pulmonary and gastrointestinal disease $(7,20)$. To eliminate the diagnostic variability that might affect the phenotypic categorization, we included only those patients with medical report of clinical symptoms who were referred to our clinic from three hospitals that were located in three separate provinces of north-west Iran. We also studied 157 unrelated, sex-matched, healthy Azeri Turkish control subjects without CF or other inflammatory diseases. The control subjects were not related to any of the patients. The phenotypic characteristics of the patients included gastro intestinal involvement, pulmonary involvement, and poor growth. Meconium ileus complication, rectal prolapse, fat in the stools, bulky and greasy stools, and stomach pain were considered as symptoms related to severe gastrointestinal involvement. Serial infections, excessive inflammation, and bronchiectasis were considered as indicators of more advanced lung disease. Inadequate exocrine pancreas function, weight loss, and malnutrition were regarded as indicators of poor growth $(7,21)$. The patient classifications were done by specialists.

\subsection{DNA Extraction}

After receiving approval from the institutional review board and ethical committee of the Tabriz University of Medical Sciences (Tabriz, Iran), approximately $4 \mathrm{~mL}$ of intravenous blood samples were collected in EDTA vacutainers and the DNA was extracted using standard methods. All subjects or their parents provided written informed consent for their participation (including the analysis of their DNA) in this study. The samples were deposited in the DNA Bank of the Liver and Gastrointestinal Disease Research Center of Tabriz University of Medical Sciences as anonymous samples.

\subsection{Cytokine Gene Polymorphisms}

Two fragments of the TNF- $\alpha$ gene promoter, including the $-1031 \mathrm{~T} / \mathrm{C}$ and $-308 \mathrm{~A} / \mathrm{G}$ polymorphism sites, were amplified by polymerase chain reaction (PCR) (22). The PCR products were digested by incubating with an appropriate restriction enzyme overnight according the manufacturer's instructions. The digested products were separated on $8 \%$ polyacrylamid gels, and the bands were visualized after ethidium bromide staining (Figures 1 and 2).

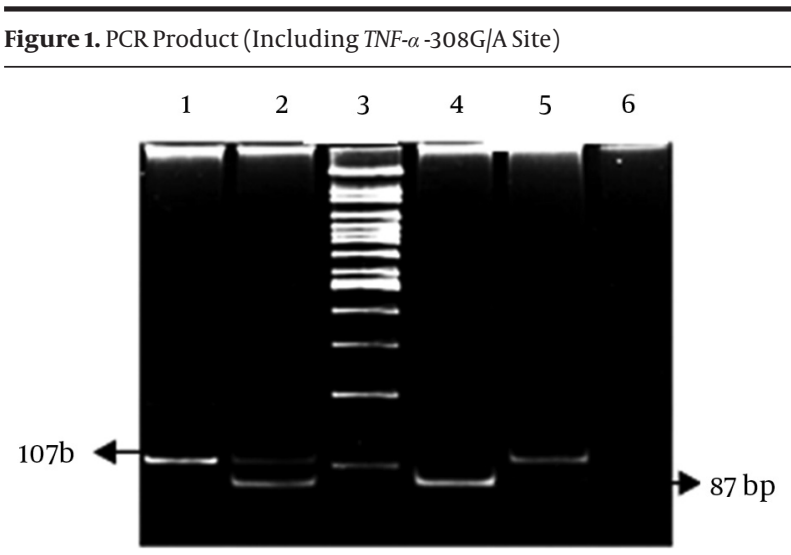

Digestion with Ncol Restriction Enzyme (5'...CCATGG...3'), 1-PCR product; 2-Heterozigote (G/A); 3-Marker (100 bp); 4-Homozigote (G/G); 5-Homozigote (A/A); 6-Water.

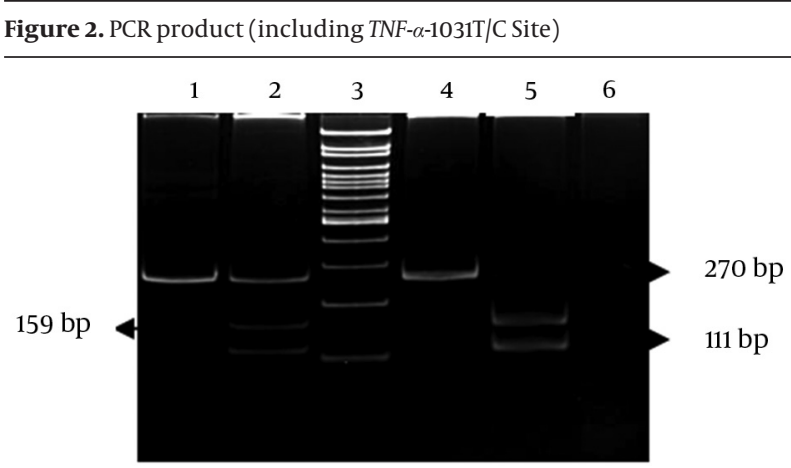

Digestion with BPI1 Restriction Enzyme (5'...GAAGAC(N)2...3'), 1-PCR product; 2-Heterozigote (T/C); 3-Marker(100 bp); 4-Homozigote(T/T); 5-Homozigote(C/C); 6-Water. 
Khorrami A et al.

\subsection{Statistical Analysis}

The allele, genotype, and haplotype frequencies were compared with the help of the Chi-square test with Yates' correction or the Fisher's exact test, wherever appropriate. $\mathrm{P}<0.05$ was regarded as statistically significant.

\section{Results}

Data for the 30 patients who were homozygous for CF $\Delta$ F508 and classified according to phenotype is presented in Table 1 . The frequency of TNF- $\alpha$ gene polymorphic variants were similar in the two groups of patients who did or did not show severe involvement of specific organs and poor growth (Tables 2 and 3). The genotype frequencies of CF patients and healthy controls conformed to the HardyWeinberg equilibrium ( $\mathrm{P}=0.95$ for CF patients and $\mathrm{P}=0.95$ for healthy control subjects). Comparison of allele and genotype frequencies of TNF- $\alpha-308 \mathrm{G} / \mathrm{A}$ and -1031C/T polymorphism showed no significant difference between the patients with non-classic CF symptoms and healthy controls. The frequencies of the TNF- $\alpha-308 \mathrm{G} / \mathrm{G}, \mathrm{G} / \mathrm{A}$, and A/A genotypes were 0.9, 0.1, and 0, respectively in CF patients, and $0.815,0.165,0.019$, respectively in healthy controls $(\mathrm{P}=$ 0.4117 by Fisher's exact test). TNF- $\alpha-308 \mathrm{G}$ allele frequencies were 0.95 in CF patients and 0.89 in healthy controls ( $\mathrm{P}=$ $0.1131, \mathrm{OR}=0.46 ; 95 \% \mathrm{CI}(0.17-1.22)$. The allele and genotype distributions of TNF- $\alpha 1031 \mathrm{~T} / \mathrm{C}$ were similar in the patient and control groups. The frequencies of the TNF- $\alpha 1031 \mathrm{~T} / \mathrm{T}$, $\mathrm{T} / \mathrm{C}$, and $\mathrm{C} / \mathrm{C}$ genotypes were $0.66,0.32$, and 0.02 , respectively in CF patients, and $0.669,0.31,0.19$, respectively in controls ( $\mathrm{P}=0.99$ by 2 tests), and the allele frequencies of TNF- $\alpha-1031 \mathrm{~T}$ were 0.82 in CF patients and 0.828 in controls $(\mathrm{P}=0.9203, \mathrm{OR}=0.57$; 95\% CI (1.337-1.85). Among the four possible haplotypes, the TNF- $\alpha-1031 \mathrm{~T},-308 \mathrm{G}$ was the most frequent in the Iranian Azeri Turkish population. The percentage of the haplotype that predisposes one for having high level of TNF- $\alpha$ (TNF- $\alpha-1031 \mathrm{C},-308 \mathrm{~A})$ was similar in nonclassic CF subjects and controls (1.25 vs. 0.95\%).

\begin{tabular}{|c|c|c|c|c|c|}
\hline Total Enrollment & $30(\Delta \mathrm{F} 508 / \Delta \mathrm{F} 508)$ & Phonotype & Malabsorption & Poor Growth & Pulmonary Involvement \\
\hline Age, month & & Severe & $8(27)$ & $16(53)$ & $15(50)$ \\
\hline $3<$ and $12>$ & $6(20)$ & & & & \\
\hline $12-24$ & $9(30)$ & & & & \\
\hline $24<$ & $15(50)$ & & & & \\
\hline Gender & & Mild & $22(73)$ & $14(47)$ & $15(50)$ \\
\hline Male & $14(47)$ & & & & \\
\hline Female & $16(53)$ & & & & \\
\hline Race, Azeri Turk & $30(100)$ & & & & \\
\hline
\end{tabular}

\begin{tabular}{|c|c|c|c|c|c|c|c|c|c|}
\hline \multirow{2}{*}{$\begin{array}{l}\text { SNP } \\
308 G / A\end{array}$} & \multicolumn{2}{|c|}{$\begin{array}{l}\text { Allele Pulmonary } \\
\text { Involvement }\end{array}$} & \multirow{2}{*}{$\begin{array}{c}\text { P Value } \\
0.99\end{array}$} & \multicolumn{2}{|c|}{$\begin{array}{c}\text { Allele Gastro Intestinal } \\
\text { Involvement }\end{array}$} & \multirow{2}{*}{$\begin{array}{c}\text { P Value } \\
1\end{array}$} & \multicolumn{2}{|c|}{ Allele Poor Growth } & \multirow{2}{*}{$\begin{array}{c}\text { P Value } \\
1.0\end{array}$} \\
\hline & $G$ & A & & $G$ & A & & $G$ & A & \\
\hline Severe & $29(96.6)$ & $1(3.4)$ & & $30(93.7)$ & $2(6.3)$ & & $15(93.7)$ & $1(6.25)$ & \\
\hline Mild & $28(93.3)$ & $2(6.7)$ & & $27(96.4)$ & $1(3.6)$ & & $42(95.4)$ & $2(4.6)$ & \\
\hline 1031T/C & $\mathrm{T}$ & C & 1 & $\mathrm{~T}$ & C & 0.12 & $\mathrm{~T}$ & C & 0.73 \\
\hline Severe & $26(76.5)$ & $8(23.5)$ & & $22(68.7)$ & $10(31.5)$ & & $13(81.2)$ & $3(18.8)$ & \\
\hline Mild & $20(76.9)$ & $6(23.1)$ & & $24(85.7)$ & $4(14.3)$ & & $33(75)$ & $11(25)$ & \\
\hline
\end{tabular}

a SNP, single nucleotide polymorphism; T and C are two alleles of 1031T/C polymorph point and G and A are two alleles of $308 \mathrm{G} / \mathrm{A}$. T and G are wild type alleles (w) while C and A are mutant alleles (m).

Data are presented as No. (\%).

\begin{tabular}{|c|c|c|c|c|c|c|c|c|c|}
\hline \multirow[t]{2}{*}{ Genotype } & \multicolumn{3}{|c|}{ Gastro intestinal } & \multicolumn{3}{|c|}{ Pulmonary } & \multicolumn{3}{|c|}{ Poor growth } \\
\hline & Severe & Mild & P Value & Severe & Mild & PValue & Severe & Mild & P Value \\
\hline$-308 G / A$ & & & 1 & & & 1 & & & 1 \\
\hline $\mathrm{G} / \mathrm{G}$ & $14(87.5)$ & $13(92.8)$ & & $14(93.3)$ & $13(86.6)$ & & $7(87.5)$ & $20(90.1)$ & \\
\hline $\mathrm{A} / \mathrm{G}$ & $2(12.5)$ & $1(8.2)$ & & $1(6.7)$ & $2(13.4)$ & & $1(12.5)$ & $2(9.9)$ & \\
\hline $\mathrm{A} / \mathrm{A}$ & $0(0)$ & $0(0)$ & & $0(0)$ & $0(0)$ & & $0(0)$ & $0(0)$ & \\
\hline$-1031 \mathrm{~T} / \mathrm{C}$ & & & 0.5 & & & 0.7 & & & 0.47 \\
\hline $\mathrm{T} / \mathrm{T}$ & $7(38.8)$ & $8(57.1)$ & & $7(87.5)$ & $9(60)$ & & $5(62.5)$ & $11(50)$ & \\
\hline $\mathrm{T} / \mathrm{C}$ & $9(61.2)$ & $6(42.9)$ & & $8(12.5)$ & $6(30)$ & & $3(37.5)$ & $11(50)$ & \\
\hline $\mathrm{C} / \mathrm{C}$ & $0(0)$ & $0(0)$ & & $0(0)$ & $0(0)$ & & $0(0)$ & $0(0)$ & \\
\hline
\end{tabular}

$\mathrm{a}_{\mathrm{T}} \mathrm{T}$ and $\mathrm{C}$ are two alleles of 1031T/C polymorph point and $\mathrm{G}$ and $\mathrm{A}$ are two alleles of 308G/A. T and $\mathrm{G}$ are wild type alleles (w) while $\mathrm{C}$ and $\mathrm{A}$ are mutant alleles (m).

$\mathrm{b}$ Data are presented as No. (\%). 


\section{Discussion}

To the best of our knowledge, this is the first study of TNF- $\alpha$ gene promoter polymorphisms related to the clinical manifestation of CF in north-west Iran. CF is a pleiotropic disorder with highly variable symptoms. The classic form of CF involves the respiratory tract, gastrointestinal tract, male reproductive tract, and sweat glands and is caused by loss-of-function mutations in the CFTR gene. The non-classic types with milder phenotype are caused by mutations that suppress but do not eliminate the function of the CFTR protein (23). Studies have shown that multiple genes, including TNF- $\alpha$, act as modifiers in CF. High levels of TNF- $\alpha$ and a disrupted balance between its protective and deleterious roles is frequently observed in CF $(24,25)$. Previous studies reported that CFTR gene is regulated by cytokines (TNF- $\alpha$ and IL-1) in a cell type-specific manner. TNF- $\alpha$ acts to reduce the abundance of CFTR mRNA post transcriptionaly in human colon cell lines (HT-29) and pulmonary cell lines $(26,27)$. Hull and Thomson (28) who studied 53 children with CF found that 20 of the patients had polymorphism in the promoter region of the TNF- $\alpha(-308 \mathrm{~A})$, which is known to be associated with higher levels of the cytokine. These children showed significantly lower FEV1 (forced expiratory volume per second) and poorer nutritional status than children without the polymorphism (28). A separate study of 180 Czech and Belgian CF patients aged 12-15 years, all of whom were homozygous for $\Delta \mathrm{F} 508$, found that the $851 \mathrm{C} / \mathrm{T}$ and $-238 \mathrm{G} / \mathrm{A}$, but not $-308 \mathrm{G} / \mathrm{A}$ TNF- $\alpha$ polymorphisms were associated with the severity of lung disease (29). Recent studies have revealed that significant proportion of patients with symptoms of non-classic CF do not carry any CFTR gene mutation. However some mutations may have been missed and were not detected (23). Studies have shown that carriers of CFTR mutation are at higher risk of CF than the general population (30). Specific alleles of other genes or unfavorable environmental factors in combination with a single CFTR mutation could potentially produce a non-classic phenotype. Therefore, we first evaluated the potential modifying effect of the polymorphisms of genes other than CFTR on the progression and severity of $\mathrm{CF}$, in patients with the same genotype, ( $\Delta \mathrm{F} 508 / \Delta \mathrm{F} 508)$, with or without specific symptoms associated with lung and gastrointestinal function and weight loss. We compared the results obtained for the two groups based on the hypothesis that adverse and beneficial genetic variants would be enriched in these two groups of disease severity. We then compared those CF patients with non-classic phenotype who did not carry CFTR mutations with healthy control subjects based on the hypothesis that although the patients may not have mutations in the CFTR locus, cumulative effect of specific alleles of multiple CF modifier genes, such as TNF- $\alpha$, may create the final phenotype. Alternatively, a combination of an undetected CFTR mutation and specific alleles of other genes (modifiers) may produce a non-classic phe- notype. However, we did not find an association between the investigated polymorphic site and the non-classic CF disease or the severity of the classic form of the disease. Although we collected data from the maximum number of CF samples that were available during the study period, further studies and with larger sample size appear to be necessary for a more complete analysis of the probable associations between TNF- $\alpha$ or other modifier genes with CF in patients of this ethnic group. The results of the present study show that TNF- $\alpha$ gene does not act as a modifier in CF disease among the Iranian Azeri Turkish population.

\section{Acknowledgements}

The authors thank all participants, patients, and their parents.

\section{Funding/Support}

This project was funded by the Center of Excellence for Biodiversity of the University of Tabriz, Iran.

\section{References}

1. Dooki MR, Akhavan-Niaki H, Juibary AG. Detecting Common CFTR Mutations by Reverse Dot Blot Hybridization Method in Cystic Fibrosis First Report from Northern Iran. Iran J Pediatr. 2011;21(1):51-7.

2. Soleti R, Porro C, Martinez MC. Apoptotic process in cystic fibrosis cells. Apoptosis. 2013;18(9):1029-38.

3. Nabholz CE, von Overbeck J. Gene-environment interactions and the complexity of human genetic diseases. J Insur Med. 2004;36(1):47-53.

4. Bonyadi M, Omrani O, Rafeey M, Bilan N. Spectrum of CFTR gene mutations in Iranian Azeri Turkish patients with cystic fibrosis. Genet Test Mol Biomarkers. 2011;15(1-2):89-92.

5. Perone C, Medeiros GS, del Castillo DM, de Aguiar MJ, Januario JN Frequency of 8 CFTR gene mutations in cystic fibrosis patients in Minas Gerais, Brazil, diagnosed by neonatal screening. Braz J Med Biol Res. 2010;43(2):134-8.

6. Farjadian S, Moghtaderi M, Kashef S, Alyasin S, Najib K, Saki F Clinical and genetic features in patients with cystic fibrosis in southwestern iran. Iran J Pediatr. 2013;23(2):212-5.

7. Antunovic SS, Lukac M, Vujovic D. Longitudinal cystic fibrosis care. Clin Pharmacol Ther. 2012;93(1):86-97.

8. Collaco JM, Cutting GR. Update on gene modifiers in cystic fibrosis. Curr Opin Pulm Med. 2008;14(6):559-66.

9. Cutting GR. Modifier genetics: cystic fibrosis. Annu Rev Genomics Hum Genet. 2005;6:237-60.

10. Buscher R, Grasemann H. Disease modifying genes in cystic fibrosis: therapeutic option or one-way road? Naunyn Schmiedebergs Arch Pharmacol. 2006;374(2):65-77.

11. Slavotinek A, Biesecker LG. Genetic modifiers in human development and malformation syndromes, including chaperone proteins. Hum Mol Genet. 2003;12 Spec No 1:R45-50.

12. Feng RN, Zhao C, Sun CH, Li Y. Meta-analysis of TNF 308 G/A polymorphism and type 2 diabetes mellitus. PLoS One. 2011;6(4).

13. Nieves-Ramirez ME, Partida-Rodriguez O, Alegre-Crespo PE, Tapia-Lugo Mdel C, Perez-Rodriguez ME. Characterization of Single-Nucleotide Polymorphisms in the Tumor Necrosis Factor alpha Promoter Region and in Lymphotoxin alpha in Squamous Intraepithelial Lesions, Precursors of Cervical Cancer. Transl Oncol. 2011;4(6):336-44.

14. Wilson AG, Symons JA, McDowell TL, McDevitt HO, Duff GW. Effects of a polymorphism in the human tumor necrosis factor alpha promoter on transcriptional activation. Proc Natl Acad Sci US A. 1997;94(7):3195-9. 
15. van Heel DA, Udalova IA, De Silva AP, McGovern DP, Kinouchi Y, Hull J, Lench NJ, Cardon LR, Carey AH, Jewell DP, Kwiatkowski D, et al. Inflammatory bowel disease is associated with a TNF polymorphism that affects an interaction between the OCT1 and NF(kappa)B transcription factors. Hum Mol Genet. 2002;11(11):1281-9.

16. Zuniga J, Vargas-Alarcon G, Hernandez-Pacheco G, Portal-Celhay C, Yamamoto-Furusho JK, Granados J. Tumor necrosis factoralpha promoter polymorphisms in Mexican patients with systemic lupus erythematosus (SLE). Genes Immun. 2001;2(7):363-6.

17. Fernandez-Celemin L, Pasko N, Blomart V, Thissen JP. Inhibition of muscle insulin-like growth factor I expression by tumor necrosis factor-alpha. Am J Physiol Endocrinol Metab. 2002;283(6):E1279-90.

18. Reid MB, Li YP. Tumor necrosis factor-alpha and muscle wasting: a cellular perspective. Respir Res. 2001;2(5):269-72.

19. Grounds MD. Reasons for the degeneration of ageing skeletal muscle: a central role for IGF-1 signalling. Biogerontology. 2002;3(1-2):19-24.

20. Shmarina G, Pukhalsky A, Petrova N, Zakharova E, Avakian L, Kapranov N, Alioshkin V, et al. TNF gene polymorphisms in cystic fibrosis patients: contribution to the disease progression. JTrans Med. 2013;11:19.

21. Mishra A, Greaves R, Massie J. The relevance of sweat testing for the diagnosis of cystic fibrosis in the genomic era. Clin Biochem Rev. 2005;26(4):135-53.

22. Bonyadi M, Jahanafrooz Z, Esmaeili M, Kolahi S, Khabazi A, Ebrahimi AA, Hajialilo M, Dastgiri S, et al. TNF-alpha gene polymorphisms in Iranian Azeri Turkish patients with Behcet's Disease. Rheumatol Int. 2009;30(2):285-9.

23. Groman JD, Meyer ME, Wilmott RW, Zeitlin PL, Cutting GR. Vari- ant cystic fibrosis phenotypes in the absence of CFTR mutations. NEngl J Med. 2002;347(6):401-7.

24. Hardin DS. GH improves growth and clinical status in children with cystic fibrosis -- a review of published studies. Eur J Endocrinol. 20 04;151 Suppl 1:S81-5.

25. Shmarina GV, Pukhalsky AL, Kokarovtseva SN, Pukhalskaya DA, Shabalova LA, Kapranov NI, Kashirskaja NJ, et al. Tumor necrosis factor-alpha/interleukin-10 balance in normal and cystic fibrosis children. Mediators Inflamm. 2001;10(4):191-7.

26. Baudouin-Legros M, Hinzpeter A, Jaulmes A, Brouillard F, Costes B, Fanen P, Edelman A, et al. Cell-specific posttranscriptional regulation of CFTR gene expression via influence of MAPK cascades on 3'UTR part of transcripts. Am J Physiol Cell Physiol. 2005;289(5):C1240-50.

27. Ramachandran S, Karp PH, Osterhaus SR, Jiang P, WohlfordLenane C, Lennox KA, Jacobi AM, Praekh K, Rose SD, Behlke MA, Xing Y, Welsh MJ, McCray PJ, et al. Post-transcriptional regulation of cystic fibrosis transmembrane conductance regulator expression and function by microRNAs. Am J Respir Cell Mol Biol. 2013;49(4):544-51.

28. Hull J, Thomson AH. Contribution of genetic factors other than CFTR to disease severity in cystic fibrosis. Thorax. 1998; 53(12):1018-21.

29. Yarden J, Radojkovic D, De Boeck K, Macek MJ, Zemkova D, Vavrova V, Vlietinck R, Cassiman JJ, Cuppens $\mathrm{H}$, et al. Association of tumour necrosis factor alpha variants with the CF pulmonary phenotype. Thorax. 2005;60(4):320-5.

30. Joos L, Pare PD, Sandford AJ. Genetic risk factors of chronic obstructive pulmonary disease. Swiss Med Wkly. 2002;132(3-4):27-37. 